\title{
Tea polyphenols protect bovine mammary epithelial cells from hydrogen peroxide-induced oxidative damage in vitro by activating NFE2L2/HMOX1 pathways
}

\author{
Y. F. Ma, ${ }^{1 *}$ L. Zhao, ${ }^{1 *}$ D. N. Coleman, ${ }^{2}$ M. Gao, ${ }^{1} \dagger$ and J. J. Loor ${ }^{3} \dagger$ \\ ${ }^{1}$ Institute of Animal Nutrition and Feed, Inner Mongolia Academy of Agriculture and Animal Husbandry Sciences, Hohhot 010031, P. R. China \\ ${ }^{2}$ Department of Animal Sciences, University of Illinois, Urbana 61801 \\ ${ }^{3}$ Department of Animal Sciences and Division of Nutritional Sciences, University of Illinois, Urbana 61801
}

\begin{abstract}
Periparturient dairy cows are likely subject to altered intracellular reduction-oxidation (redox) balance due to the high metabolic rates and physiological adaptations occurring around parturition. Such conditions could induce oxidative damage. In nonruminants, it is well established that nuclear factor erythroid 2 like 2 (NFE2L2) is a critical transcription factor for maintaining cellular redox balance by inducing adaptive responses against oxidative stress (OS) that can otherwise lead to uncontrolled inflammation. Tea polyphenols (TP), the major polyphenolic constituents of green tea, are potent antioxidants that could exert protective effects on bovine mammary epithelial cells (BMEC) by scavenging free radicals. We used NFE2L2 short interfering RNA (siRNA) to downregulate NFE2L2 expression in cultured BMEC to investigate whether TP could inhibit $\mathrm{H}_{2} \mathrm{O}_{2}$-induced $\mathrm{OS}$ by activating the NFE2L2/heme oxygenase-1 (HMOX1) pathway. Isolated BMEC were exposed to $\mathrm{H}_{2} \mathrm{O}_{2}(600 \mu M)$ for $6 \mathrm{~h}$ to induce OS. Optimal doses of TP $(0,60,80$, and 100 $\mu \mathrm{g} / \mathrm{mL}$ ) were evaluated by pretreatment of BMEC for $0,2,4,6,8,12$, and $24 \mathrm{~h}$, followed by a $\mathrm{H}_{2} \mathrm{O}_{2}(600 \mu M)$ challenge for $6 \mathrm{~h}$. The BMEC were transfected with NFE2L2-siRNA for $48 \mathrm{~h}$, pretreated with $100 \mu \mathrm{g} / \mathrm{mL}$ of $\mathrm{TP}$ for $12 \mathrm{~h}$, then challenged by $600 \mu M \mathrm{H}_{2} \mathrm{O}_{2}$ for $6 \mathrm{~h}$. Results revealed that after $\mathrm{H}_{2} \mathrm{O}_{2}$ exposure a concentration of TP of $100 \mu \mathrm{g} / \mathrm{mL}$ during a 12-h incubation led to greater cell viability, protein, and mRNA abundance of NFE2L2, and lower intracellular reactive oxygen species (ROS) accumulation. In addition, transfection with NFE2L2-siRNA decreased abundance of NFE2L2 and HMOX1 in spite of exogenous TP supplementation,
\end{abstract}

Received May 11, 2018.

Accepted October 25, 2018.

*These authors contributed equally to this study.

†Corresponding authors: gmyh1588@126.com and jloor@illinois.edu whereas ROS production was increased in response to exogenous $\mathrm{H}_{2} \mathrm{O}_{2}(600 \mu M)$. Overall, TP had beneficial effects on redox balance in BMEC, slowing down cellular OS-related injury through decreasing the production of ROS and enhancing mechanisms controlled at least in part by the NFE2L2/HMOX1 pathway.

Key words: tea polyphenol, oxidative stress, bovine mammary epithelial cell

\section{INTRODUCTION}

Physiologic changes during the periparturient (transition) period often render cows more susceptible to health disorders, and a growing body of data underscore that the regulation of those tissue-level processes occurs at the molecular (mRNA, protein) and enzymatic level (Loor, 2010; Loor et al., 2013). Among the most critical challenges facing dairy cows around parturition, controlling oxidative stress (OS) is paramount because it could contribute to dysfunctional inflammatory responses (Sordillo and Raphael, 2013; Abuelo et al., 2016) that could impair efficiency (Bertoni et al., 2008).

In dairy cows, compelling evidence indicates that production of reactive oxygen species (ROS) plays a critical role in OS and can alter intracellular reductionoxidation (redox) balance (Bertoni et al., 2008; Zhou et al., 2016a). In fact, work with nonruminant species has verified that overproduction of intracellular ROS is a crucial determinant in the mechanism by which various stressors might injure cells leading to diverse pathologic disorders (Soberanes et al., 2006). Among the various types of ROS, hydrogen peroxide $\left(\mathrm{H}_{2} \mathrm{O}_{2}\right)$ is particularly important from a physiologic standpoint because it can be generated by normal cellular processes, including oxidative metabolism. Although the etiology of metabolic disorders in periparturient cows is multifaceted (Zhou et al., 2016a,b), evidence indicates that OS caused by excessive production of $\mathrm{H}_{2} \mathrm{O}_{2}$ could be an important contributor (Jin et al., 2016). In addition, the production of malondialdehyde (MDA), 8-iso-prostaglandin 
(8-iso-PG), protein carbonyl (PC), and 8-hydroxydeoxyguanosine (8-OHdG) could be used to evaluate OS status. The levels of MDA (Ljubisavljevic et al., 2013) and 8-iso-PG (Milaneschi et al., 2013) provide information on levels of lipid peroxidation, the content of PC (Weber et al., 2015) reflects the extent of protein damage, and 8-OHdG (Kaneko et al., 1996) content is a marker of DNA damage.

At least in nonruminants, the transcription regulator nuclear factor erythroid 2 like 2 (NFE2L2) is considered the master regulator of cellular redox balance, which can induce the expression of antioxidant and detoxification enzymes and downstream phase-II enzymes such as superoxide dismutase (SOD), glutathione peroxidase (GSH-Px), glutathione-S-transferase, catalase, heme oxygenase-1 (HMOX1), NAD(P)H: quinone oxidoreductase-1 (NQO1), glutamate-cysteine ligase catalytic subunit (GCLC), and glutamatecysteine ligase modifier subunit (GCLM; Nguyen et al., 2003; Denzer et al., 2016). When not stimulated, NFE2L2 is sequestered in the cytoplasm where it associates with Kelch-like ECH-associated protein 1 (Keap1; Hayes and McMahon, 2001; Jaiswal, 2004), considered a cytosolic inhibitor of NFE2L2. Disrupting the NFE2L2-Keap1 interaction leads to activation of NFE2L2 (Zhang et al., 2010). Under stressful conditions, however, NFE2L2 is released from Keap1 and translocates to the nucleus where it binds to conserved antioxidant response elements (ARE) on target genes (Itoh et al., 1997; Kansanen et al., 2013).

Activation of the NFE2L2-ARE pathway can affect oxidative status of cells and provides robust protection against oxidative challenge (Kobayashi and Yamamoto, 2006). Previous studies revealed that NFE2L2 not only regulates transcription of genes encoding electrophileinduced phase-II enzymes, but is also critical in the regulation of various antioxidant protein-encoding genes in response to OS (Ishii et al., 2000) and inflammation (Itoh et al., 2004). Among the phase-II detoxifying enzymes, HMOX1, a cytoprotective protein, exerts cellular defense functions against various compounds produced during OS (Ryter and Choi, 2005; Kweon et al., 2006) and was first identified as a target gene of highly expressed transcription regulators in periparturient cow liver (Loor, 2010; Khan et al., 2014). More importantly, previous studies in cultured bovine mammary epithelial cells (BMEC) revealed that NFE2L2 controls HMOX1, suggesting that the NFE2L2/ARE pathway is functional in the mammary gland and may confer a mechanism of protection against OS (Ma et al., 2018b). Thus, identifying potential exogenous regulators of NFE2L2 might provide the foundation for future research on their feasibility for practical use in dairy cow management.
Numerous polyphenols that scavenge free radicals have been identified and proposed as therapeutic agents to counteract OS-induced disorders in humans (Vitaglione et al., 2004). Green tea polyphenols (TP), which compose 30 to $40 \%$ of extractable solids from dried green tea leaves, exhibit significant antioxidant properties (Frei and Higdon, 2003). In addition, polyphenols can interact with cellular defense systems including HMOX1 (Inamdar et al., 1996) and NQO1 (Favreau and Pickett, 1995). Thus, we hypothesize that TP could play an antioxidative role in BMEC during OS challenges at least in part by activating the HMOX1 or NQO1.

Whether TP could inhibit $\mathrm{H}_{2} \mathrm{O}_{2}$-induced $\mathrm{OS}$ in BMEC and the underlying molecular mechanisms is not known. Thus, the aim of the present study was to silence NFE2L2 expression through short interfering RNA (siRNA) and investigate whether TP could inhibit $\mathrm{H}_{2} \mathrm{O}_{2}$-induced OS via specific phase-II enzymes that are controlled through activation of the NFE2L2/ ARE pathway. The relevance of this work is underscored by recent data demonstrating not only an increase in phosphorylation status of NFE2L2 in mammary tissue during the periparturient period, but also upregulation of antioxidant gene networks (Han et al., 2018a,b).

\section{MATERIALS AND METHODS}

\section{Isolation of BMEC}

To ensure that enough viable cells were available, mammary tissue was obtained from five 4-yr-old healthy lactating multiparous grazing Chinese Holstein cows at a similar stage of lactation (200 \pm 5 DIM) selected from the Inner Mongolia Academy of Agriculture and Animal Husbandry Sciences. Animals were killed at a local slaughterhouse (Hohhot, China). The midpoint area of left rear side of the udder was clipped and surgically scrubbed. Approximately $150 \mathrm{mg}$ of fresh tissue from each cow was removed and placed in sterilized tubes containing ice-cold Dulbecco's phosphate buffered saline (DPBS, Sigma-Aldrich, St. Louis, MO) and immediately transported to the laboratory. The samples were washed 3 times with DPBS and cut into $1-\mathrm{mm}^{3}$ pieces. Tissue was transferred with tweezers onto sterile, plastic cell culture dishes (Corning Inc., Corning, NY). Mammary tissue with collagenase was kept for $1 \mathrm{~h}$ in a humidified incubator at $37^{\circ} \mathrm{C}$ in an atmosphere of $5 \% \mathrm{CO}_{2}$ and $95 \%$ air. Subsequently, tissue extracts were centrifuged at $400 \times g$ for $5 \mathrm{~min}$ at room temperature in tubes containing an $80-\mu \mathrm{m}$ nylon mesh strainer and centrifuged. The precipitate was suspended with $1 \mathrm{~mL}$ of basal medium and then transferred into culture dishes followed by addition of 
Table 1. Primer sequences for the nuclear factor erythroid 2 like 2 (NFE2L2)-short interfering RNA (siRNA) used in the in vitro experiments with bovine mammary epithelial cells (BMEC)

\begin{tabular}{lll}
\hline Primer & \multicolumn{2}{l}{ Primer sequence $\left(5^{\prime} \rightarrow 3^{\prime}\right.$ orientation $)$} \\
\hline NFE2L2-siRNA1 & Sense & TTGCTCAAAGAAAGAGGAGAA \\
& Antisense & TTCTCCTCTTTCTTTGAGCAA \\
NFE2L2-siRNA2 & Sense & ACTGGATAAAGAAGTAGGTAA \\
NFE2L2-siRNA3 & Antisense & TTACCTACTTCTTTATCCAGT \\
& Sense & CTGGAGCAAGATTTAGATCAT \\
& Antisense & ATGATCTAAATCTTGCTCCAG \\
\hline
\end{tabular}

$4 \mathrm{~mL}$ of basal medium and maintained in a humidified incubator at $37^{\circ} \mathrm{C}$ and $5 \% \mathrm{CO}_{2}$. The basal medium was composed of $95.74 \mathrm{~mL}$ of Dulbecco's modified Eagle medium (DMEM; 12400-024, Gibco, Grand Island, $\mathrm{NY}$ ), $2 \mathrm{~mL}$ of penicillin streptomycin (Gibco), $0.5 \mathrm{~mL}$ of $0.5 \%$ insulin transferrin solution (Gibco), $100 \mu \mathrm{L}$ of $1 \mu \mathrm{g} / \mathrm{mL}$ hydrocortisone (Gibco), $100 \mu \mathrm{L}$ of $2.5 \mu \mathrm{g} / \mathrm{mL}$ amphotericin B (Gibco), $10 \mu \mathrm{L}$ of $10 \mathrm{ng} / \mathrm{mL}$ epidermal growth factor (Gibco), $50 \mu \mathrm{L}$ of $5 \mu \mathrm{g} / \mathrm{mL}$ prolactin (Gibco), and $1.5 \mathrm{~mL}$ of $4 \mathrm{mmol} / \mathrm{L}$ glutamine (Gibco). Medium was prepared and kept at $4^{\circ} \mathrm{C}$ until use. The basal medium was replaced with fresh basal medium every 2 to $3 \mathrm{~d}$ until the cells were distributed across the bottom of the dish. Subsequently, epithelial cells were enriched by selective detachment with trypsinization using $0.25 \%$ trypsin (Gibco). After 3 min of trypsinization, fibroblasts were removed by washing with DPBS. The epithelial cells attached to the dish surface were allowed to grow by addition of fresh medium. The BMEC were continuously purified using the same method. The purified BMEC with positive expression of CK-18 (Supplemental Figure S1; https://doi.org/10.3168/jds .2018-15047) demonstrating the epithelial cell lineage (Wang et al., 2014) were seeded at a density of $5 \times$ $10^{5}$ cells in culture flasks and continuously subcultured up to 4 passages. For cryopreservation, $1 \times 10^{6}$ cells/ $\mathrm{mL}$ was suspended in freezing medium. A supraphysiologic concentration of $600 \mu M \mathrm{H}_{2} \mathrm{O}_{2}$ was applied to the BMEC to induce OS (Ma et al., 2018a,b).

\section{RNA Interference}

Three siRNA specific for NFE2L2 (NFE2L2-siRNA1, NFE2L2-siRNA2, and NFE2L2-siRNA3) and a scrambled sequence (scrambled siRNA, control) were designed and synthesized by Shanghai Genechem Co., Ltd. (Shanghai, China). The NFE2L2-siRNA1, 2, 3, and primer sequence are presented in Table 1. The BMEC were transfected in antibiotic-free medium following the manufacturer's instructions (Shanghai Genechem Co., Ltd.), as described previously (Ma et al., 2018a,b). Briefly, BMEC were routinely trypsinized and resus- pended to $2 \times 10^{6}$ cells $/ \mathrm{mL}$ in basal medium without antibiotics, and cells were then set aside at $37^{\circ} \mathrm{C}$. After $24 \mathrm{~h}$, the cells were transfected with NFE2L2-siRNA. After incubation for $5 \mathrm{~min}$ at $37^{\circ} \mathrm{C}$, the siRNA and lipofectamine were mixed, incubated at room temperature for an additional 20 min, then added to each well. The cell suspension that was previously set aside was transferred to the same wells containing the complex and the cell suspension was mixed by gently rocking the plates back and forth. The basal medium was replaced by the same fresh medium $12 \mathrm{~h}$ after transfection. The BMEC were cultured for another $36 \mathrm{~h}$ in basal medium to reach $80 \%$ transfection efficiency. Transfected cells were then cultured in serum and antibiotic free medium, and then subjected to $600 \mu M \mathrm{H}_{2} \mathrm{O}_{2}$ for $6 \mathrm{~h}$. Protein and mRNA expression of NFE2L2 in NFE2L2silenced and control cultures was measured to screen for the optimal NFE2L2-specific siRNA.

\section{Cell Culture and Treatments}

The BMEC with and without NFE2L2 siRNA cultured in serum- and antibiotic-free medium (either preincubated with $100 \mu \mathrm{g} / \mathrm{mL}$ of TP for $12 \mathrm{~h}$ or not) were treated with $600 \mu M \mathrm{H}_{2} \mathrm{O}_{2}$, a supraphysiological dosage to induce significant OS, or without $\mathrm{H}_{2} \mathrm{O}_{2}$ (control) for $6 \mathrm{~h}$. Specific treatments were control, $\mathrm{H}_{2} \mathrm{O}_{2}$ $(600 \mu M)$, TP (no $\left.\mathrm{H}_{2} \mathrm{O}_{2}\right)$, TP $\left(600 \mu M \mathrm{H}_{2} \mathrm{O}_{2}\right)$, and NFE2L2-siRNA3-TP $\left(600 \mu M \mathrm{H}_{2} \mathrm{O}_{2}\right)$. These were used for measuring BMEC survival rate, production of ROS, and mRNA expression of NFE2L2, and downstream genes in cultures were measured.

\section{BMEC Survival Rate Assay}

To quantify BMEC survival rate, cells were plated at a density of $2 \times 10^{6}$ cells per well in 6 -well plates overnight. Cells were then transfected with NFE2L2-siRNA3. At $48 \mathrm{~h}$ after transfection, the culture medium was switched to serum-free, antibiotic-free DMEM, and cells were then exposed to $600 \mu M \mathrm{H}_{2} \mathrm{O}_{2}$ for $6 \mathrm{~h}$. The BMEC survival rate was determined using the MTT [3-(4,5-di- 
methylthiazol-2-yl)-5-(3-carboxymethoxyphenyl)-2-(4sulfophenyl)-2H-tetrazolium] assay kit (G3582, Promega, Madison, WI) according to the manufacturer's instructions (https://www.promega.com/products/cell -health-assays/cell-viability-and-cytotoxicity-assays/ celltiter-96-aqueous-one-solution-cell-proliferation -assay-_mts_/?catNum=G3582). Briefly, $20 \mu \mathrm{L} /$ well of MTT was added to each well and incubated for 4 $\mathrm{h}$ at $37^{\circ} \mathrm{C}$. Subsequently, $150 \mu \mathrm{L}$ of dimethyl sulfoxide (DMSO, Sigma-Aldrich) was added to each well and incubated for $10 \mathrm{~min}$ at $37^{\circ} \mathrm{C}$. Lastly, the absorbance at $490 \mathrm{~nm}$ was determined with a microplate reader (Molecular Devices, Sunnyvale, CA).

\section{Detection of OS Indicators}

The activities of SOD and GSH-Px, and the content of $\mathrm{PC}$ and MDA in BMEC were determined by using spectrophotometric diagnostic kits from Nanjing Jiancheng Biotechnology Institute (Nanjing, China) according to the manufacturer's protocols. In brief, BMEC were washed with PBS and incubated with fresh DMEM (Gibco, Grand Island, NY) at $37^{\circ} \mathrm{C}$ for 35 min, respectively, and then $1 \times 10^{6}$ cells were harvested and suspended in PBS. Absorbance was detected at 560 $\mathrm{nm}$ (SOD), $420 \mathrm{~nm}$ (GSH-Px), $450 \mathrm{~nm}$ (PC), and 532 $\mathrm{nm}$ (MDA) and was recorded with a $722 \mathrm{~N}$ spectrophotometer(Scientific Instrument Co., Ltd., Shanghai, China).

The content of 8-OHdG and 8-iso-PG in BMEC were determined via ELISA kits (Nanjing Jiancheng Biotechnology Institute) according to the manufacturer's protocols. In brief, BMEC were washed with PBS and incubated with fresh DMEM (Gibco) at $37^{\circ} \mathrm{C}$ for 35 min, respectively, and then $1 \times 10^{6}$ cells were harvested and suspended in PBS. Absorbance was detected at 450 $\mathrm{nm}$ (8-OHdG and 8-iso-PG) in a Microplate reader (Multiskan MS352, Labsystems, Helsinki, Finland). The limits of detection of 8-OHdG and 8-iso-PG were 10-300 and 5-150 ng/L, respectively. The assay performance details are included in Supplemental Table S1 (https://doi.org/10.3168/jds.2018-15047).

\section{Intracellular ROS Detection}

A dichlorofluorescein staining assay was used to detect intracellular ROS. Briefly, BMEC were washed with PBS and incubated with fresh DMEM containing $10 \mu M$ dichlorofluorescein at $37^{\circ} \mathrm{C}$ for $35 \mathrm{~min}$, then $1 \times$ $10^{6}$ cells were harvested and suspended in PBS. The optical density at $450 \mathrm{~nm}$ was recorded with a microplate reader (Molecular Devices).

\section{RNA Isolation, cDNA Synthesis, and Quantitative PCR}

Total RNA was isolated from $60 \mathrm{mg}$ of BMEC using the miRNeasy kit (Qiagen, Hilden, Germany) following the manufacturer's protocols. Samples were treated on-column with DNaseI (Qiagen), quantification was assessed using the NanoDrop ND-1000 (NanoDrop Technologies, Wilmington, DE), and RNA quality was measured using an Agilent 2100 Bioanalyzer (Agilent, Santa Clara, CA). All samples had an RNA integrity number factor greater than 6.3. The quantitative PCR was performed as described previously (Osorio et al., 2014) to determine the relative mRNA abundance of NFERL2, HMOX1, NQO1, GCLC, GCLM, and TUBB (tubulin $\beta$; internal control). All reactions were run in triplicate. The primers of NFE2L2 and 4 phase-II detoxifying enzyme in the NFE2L2-ARE signaling pathway used for quantitative reverse-transcription PCR are listed in Table 2.

\section{Western Blotting}

After treatment, cells were washed twice with $4^{\circ} \mathrm{C}$ PBS (0.01 M, pH 7.2-7.3) and were then lysed with RIPA protein lysate (Beyotime Institute of Biotechnology, Shanghai, China). Total protein was extracted from BMEC using a tissue protein extraction reagent (catalog no. 78510, Thermo Scientific, Waltham, MA) containing inhibitor cocktail $(100 \times$, catalog no. 78442, Thermo Scientific). Total protein concentration was determined using the BCA Protein Assay Kit (Sigma-Aldrich). Protein samples were boiled for $20 \mathrm{~min}$ at $100^{\circ} \mathrm{C} ; 50 \mathrm{mg}$ of

Table 2. Primers for mRNA expression analysis of nuclear factor erythroid 2 like 2 (NFE2L2) and 4 phase-II detoxifying enzyme in the nuclear factor erythroid 2 like 2 (NFE2L2)-antioxidant response element signaling pathway in bovine mammary epithelial cells (BMEC)

\begin{tabular}{llll}
\hline Gene name & Forward primer $\left(5^{\prime} \rightarrow 3^{\prime}\right)$ & Reverse primer $\left(5^{\prime} \rightarrow 3^{\prime}\right)$ & Accession no. \\
\hline NFE2L2 & CCAGCACAACACATACCA & TAGCCGAAGAAACCTCATT & 001011678.2 \\
HMOX1 & GAACGCAACAAGGAGAAC & CTGGAGTCGCTGAACATAG & 001014912.1 \\
NQO1 & CAACAGACCAGCCAATCA & ACCTCCCATCCTTTCCTC & 001034535.1 \\
GCLC & ATTGGGTGGAGAGTGGAA & ACAGCGGGATGAGAAAG & 001083674.1 \\
GCLM & CCGATGAAAGAGAAGAAATG & CAACAGGAGGTGAAGCAA & 001038143.1 \\
\hline
\end{tabular}


total protein per lane was resolved by $10 \%$ SDS-PAGE (Bio-Rad, Hercules, CA) and then transferred from the gel to a polyvinylidene difluoride membrane $(0.45 \mu \mathrm{m}$, Millipore, Billerica, MA). PageRuler Plus Prestained Protein Ladder (Fermentas, Hanover, MD) was used to confirm protein electrophoresis. Membranes were blocked in Tris-buffered saline (TBST; $50 \mathrm{~m} M$ Tris, $\mathrm{pH}$ 7.6, $150 \mathrm{mM} \mathrm{NaCl}$, and $0.1 \%$ Tween 20), which contains 5\% (wt/vol) nonfat dry milk for $2 \mathrm{~h}$ at room temperature with gentle agitation. The membranes were then incubated in TBST-containing antibodies to NFE2L2 (catalog no. ab137550, Abcam, Cambridge, MA), HMOX1 (catalog no. ab13248, Abcam), NQO1 (catalog no. ab 28947, Abcam), GCLC (catalog no. ab 80841, Abcam), and GCLM (catalog no. ab81445, Abcam) with gentle agitation at $4^{\circ} \mathrm{C}$ overnight. After incubating with primary antibody, the membranes were washed and incubated with HRP-conjugated secondary antibodies (HRP-labeled sheep anti-mouse, 1:50,000, and HRP-labeled sheep anti-rabbit, 1:50,000; catalog no. ab6721; Abcam) in TBST for $1 \mathrm{~h}$ at room temperature. The membranes were washed and then incubated with ECL reagent (catalog no. 170-5060, Bio-Rad). Beta-Tubulin (catalog no. ab56676; Abcam) was used as an internal control. The images were captured using Chemi DOC MP (Bio-Rad). The intensities of the bands were measured with Image-Pro Plus 6.0 software (Media Cybernetics Inc., Rockville, MD).

\section{Statistical Analysis}

In the preliminary experiments, the effects of time $(0$, $6,8,12$, and $24 \mathrm{~h})$ and dose of $\mathrm{TP}(0,60,80$, and 100 $\mu \mathrm{g} / \mathrm{mL}$ ) were analyzed using 1-way ANOVA followed by a Student-Newman-Keuls multiple-comparison with the MIXED procedure of SAS 9.0 (SAS Institute Inc., Cary, NC). The fixed effects in the model were time and dose of TP. For subsequent experiments evaluating the effect of TP $(100 \mu \mathrm{g} / \mathrm{mL})$ we used an ANOVA followed by Student-Newman-Keuls multiple-comparison using SAS 9.0 (SAS Institute Inc.). The fixed effect was treatment. In all cases the random effect was BMEC. For the more independent variables, data were analyzed as a $2 \times 2 \times 2$ factorial arrangement of treatments using SAS 9.0 (SAS Institute Inc.). The 3 factors were TP, $\mathrm{H}_{2} \mathrm{O}_{2}$, and NFE2L2-siRNA (siRNA), each containing 2 levels ("yes," it was added/silenced; or "no," it was not added/silenced). The model tested the effects of the 3 factors, and the interactions between the 3 factors: TP $\times \mathrm{H}_{2} \mathrm{O}_{2}$, siRNA $\times \mathrm{TP}$, siRNA $\times \mathrm{H}_{2} \mathrm{O}_{2}$, and siRNA $\times \mathrm{TP}$ $\times \mathrm{H}_{2} \mathrm{O}_{2}$. Least squares means and standard errors were determined using the LSMEANS statement and means were separated using the PDIFF statement. Data for significant triple interactions are presented in graphs.
Five replicate cultures were done for each treatment in each experiment. All data are expressed as means \pm standard error of the means for the indicated number of independent experiments performed. Significance was declared at $P \leq 0.05$ and tendencies as $P \leq 0.10$.

\section{RESULTS}

\section{Screening for TP Optimum Conditions}

Pretreatment of BMEC with 0 to $100 \mu \mathrm{g} / \mathrm{mL}$ of TP for 0 to $12 \mathrm{~h}$ elicited a time- and dose-dependent increase of cell survival rate, with the highest response when the cells were pretreated with $100 \mu \mathrm{g} / \mathrm{mL}$ of TP for $12 \mathrm{~h}(P<0.01$; Table 3$)$. To further verify whether $100 \mu \mathrm{g} / \mathrm{mL}$ of $\mathrm{TP}$ was the optimum concentration to protect BMEC against OS and assess whether TP elicits antioxidant effects, BMEC were pretreated with 60 , 80 , and $100 \mu \mathrm{g} / \mathrm{mL}$ for $12 \mathrm{~h}$, followed by $\mathrm{H}_{2} \mathrm{O}_{2}(600 \mu M)$ challenge for an additional $6 \mathrm{~h}$. We then analyzed cell survival rate (Figure 1A), SOD (Figure 1B), and GSHPx (Figure 1C) activity, ROS (Figure 1D) and MDA (Figure 1E) production, caspase-3 activity (Figure 1F), $\mathrm{PC}$ (Figure 1G), 8-OHdG (Figure 1H), and 8-iso-PG (Figure 1I) content in control and oxidative damaged BMEC. The performance characteristics of the assays of 8-OHdG and 8-iso-PG were detected (Supplemental Table S1; https://doi.org/10.3168/jds.2018-15047).

Results revealed that compared with the control, the treatment of cells with $600 \mu M \mathrm{H}_{2} \mathrm{O}_{2}$ for $6 \mathrm{~h}$ decreased the cell survival rate $(P<0.01)$ and SOD and GSH-Px activity $(P<0.01)$, and enhanced ROS and MDA production $(P<0.01)$, caspase-3 activity $(P<0.01)$, PC, 8 -OHdG, and 8 -iso-PG content $(P<0.01)$. However, after pretreatment of cells with 60,80 , and $100 \mu \mathrm{g} / \mathrm{mL}$ of TP for $12 \mathrm{~h}$ followed by $\mathrm{H}_{2} \mathrm{O}_{2}(600 \mu M)$ challenge for $6 \mathrm{~h}$, the cell survival rate $(P<0.05)$, SOD and GSH-Px activity $(P<0.05)$ induced by $\mathrm{H}_{2} \mathrm{O}_{2}$ were significantly increased, whereas ROS and MDA production $(P<$ $0.05)$, caspase- 3 activity $(P<0.05), \mathrm{PC}, 8-\mathrm{OHdG}$, and 8-iso-PG content $(P<0.05)$ induced by $\mathrm{H}_{2} \mathrm{O}_{2}$ were significantly decreased compared with the control.

The cell survival rate increased to a maximum (95.5\%) when the concentration of TP was $100 \mu \mathrm{g} / \mathrm{mL}$, which was significantly higher than $60 \mu \mathrm{g} / \mathrm{mL}(77.0 \%$; $P<0.01)$ and $80 \mu \mathrm{g} / \mathrm{mL}$ of $\mathrm{TP}$ group $(81.8 \% ; P<$ $0.05)$. Activity of SOD and GSH-Px $(175.5 \mathrm{U} / \mathrm{mL}$ and $785.9 \mathrm{U} / \mathrm{L}$ ) in the cells pretreated with $100 \mu \mathrm{g} / \mathrm{mL}$ of $\mathrm{TP}$ was higher than in cells pretreated with $60 \mu \mathrm{g} /$ $\mathrm{mL}$ of $\mathrm{TP}(115.2 \mathrm{U} / \mathrm{mL}, 698.7 \mathrm{U} / \mathrm{L} ; P<0.01)$ and $80 \mu \mathrm{g} / \mathrm{mL}$ of TP $(136.7 \mathrm{U} / \mathrm{mL}, 742.5 \mathrm{U} / \mathrm{L} ; P<0.01)$, respectively.

The concentrations of ROS and MDA decreased to a minimum $(1,282 \mathrm{pg} / \mathrm{mL}, 38.0 \mathrm{mM})$ when TP was sup- 
plied at $100 \mu \mathrm{g} / \mathrm{mL}$, which was significantly less than $60 \mu \mathrm{g} / \mathrm{mL}$ of TP $(2,672.9 \mathrm{pg} / \mathrm{mL}, 66.3 \mathrm{mM} ; P<0.01)$ and $80 \mu \mathrm{g} / \mathrm{mL}$ of TP $(2,353.8 \mathrm{pg} / \mathrm{mL}, 56.9 \mathrm{mM} ; P<$ 0.01 ), respectively. The concentration of $\mathrm{PC}, 8-\mathrm{OHdG}$ and 8 -iso-PG decreased to a minimum $(0.8 \mathrm{nmol} / \mathrm{mg}$, $144 \mathrm{ng} / \mathrm{L}, 67.2 \mathrm{ng} / \mathrm{L})$ when the concentration of $\mathrm{TP}$ was $100 \mu \mathrm{g} / \mathrm{mL}$, which was significantly less than 60 $\mu \mathrm{g} / \mathrm{mL}$ of TP $(1.0 \mathrm{nmol} / \mathrm{mg}, 234.2 \mathrm{ng} / \mathrm{L}, 98.6 \mathrm{ng} / \mathrm{L})$ $(P<0.01)$ and $80 \mu \mathrm{g} / \mathrm{mL}$ of TP $(0.8 \mathrm{nmol} / \mathrm{mg}, 182.6$ $\mathrm{ng} / \mathrm{L}, 85.3 \mathrm{ng} / \mathrm{L} ; P<0.01)$, respectively. Similarly, the activity of caspase-3 (144.0) in the cells pretreated with $100 \mu \mathrm{g} / \mathrm{mL}$ of $\mathrm{TP}$ was significantly less than that in cells pretreated with $60 \mu \mathrm{g} / \mathrm{mL}$ of TP $(185.4 ; P<$ $0.05)$ and $80 \mu \mathrm{g} / \mathrm{mL}$ of TP $(169)(P<0.05)$. Thus, the pretreatment of cells with $100 \mu \mathrm{g} / \mathrm{mL}$ of TP for $12 \mathrm{~h}$ was the optimum amount chosen for subsequent experiments to assess the antioxidant effects of TP in BMEC.

\section{Cytoprotective Effects of TP Against OS in BMEC}

To examine the cytoprotective effect of TP against OS in BMEC, we further evaluated whether $\mathrm{TP}$ was able to induce NFE2L2 expression (Figure 2). The results revealed that TP significantly upregulated NFE2L2 mRNA expression in a dose-dependent manner under OS, and NFE2L2 mRNA expression induced by TP was highest when the content of TP was $100 \mu \mathrm{g} / \mathrm{mL}$ under OS $(P<0.01)$. The results also revealed that the treatment of cells with $600 \mu M$ of $\mathrm{H}_{2} \mathrm{O}_{2}$ for $6 \mathrm{~h}$ reduced the mRNA expression of NFE2L2 by $61 \%$ compared with the control cultures $(P<0.05)$. However, compared with the control, after the pretreatment of the cells with $100 \mu \mathrm{g} / \mathrm{mL}$ of TP for $12 \mathrm{~h}$, followed by $\mathrm{H}_{2} \mathrm{O}_{2}$ $(600 \mu \mathrm{M})$ challenge for $6 \mathrm{~h}$, the mRNA expression of NFE2L2 significantly increased by 2.7 -fold $(P<0.01)$.
Without OS, the treatment of cells with $100 \mu \mathrm{g} / \mathrm{mL}$ of TP for $12 \mathrm{~h}$ led to a 3.2-fold increase in mRNA expression of NFE2L2 $(P<0.01)$ compared with control cultures (Figure 3A). In addition, after pretreatment of cells with $100 \mu \mathrm{g} / \mathrm{mL}$ of TP for $12 \mathrm{~h}$ followed by $\mathrm{H}_{2} \mathrm{O}_{2}$ $(600 \mu M)$ challenge for $6 \mathrm{~h}$, the protein expression of NFE2L2 was increased compared with the control and $\mathrm{H}_{2} \mathrm{O}_{2}$ cultures $(P<0.01$; Figure $3 \mathrm{~B})$. Therefore, TP can increase the protein and $\mathrm{mRNA}$ expression of NFE2L2 in BMEC with or without OS.

\section{Verification and Screening of NFE2L2-SiRNA Interference Fragment}

Compared with the control cultures, the BMEC transfected with NFE2L2-siRNA1, NFE2L2-siRNA2, and NFE2L2-siRNA3 led to lower abundance of both NFE2L2 protein (Figure 4A) and mRNA (Figure $4 \mathrm{~B})$ with the best interference efficiency achieved with NFE2L2-siRNA3 $(>50 \% ; P<0.01)$. Therefore, NFE2L2-siRNA3 was chosen as the interference fragment for subsequent experiments.

\section{Effect of $\mathrm{H}_{2} \mathrm{O}_{2}$ on Survival Rate of BMEC After NFE2L2-siRNA3 Interference}

The survival rate of BMEC was measured after the pretreatment of cells with $100 \mu \mathrm{g} / \mathrm{mL}$ of $\mathrm{TP}$ for $12 \mathrm{~h}$, followed by $\mathrm{H}_{2} \mathrm{O}_{2}(600 \mu M)$ challenge for $6 \mathrm{~h}$. There was a tendency $(P=0.10)$ for a siRNA $\times$ TP $\times \mathrm{H}_{2} \mathrm{O}_{2}$ interaction for BMEC survival rate (Figure $5)$. Except with the TP treatment $(P=0.19)$, compared with the control cultures, the survival rate of BMEC was significantly decreased $(P<0.05)$ by all treatments. Compared with cells treated with $\mathrm{H}_{2} \mathrm{O}_{2}$

Table 3. Effect of different concentrations and incubation times with tea polyphenols (TP) on the proliferation rate of bovine mammary epithelial cells (BMEC) ${ }^{1}$

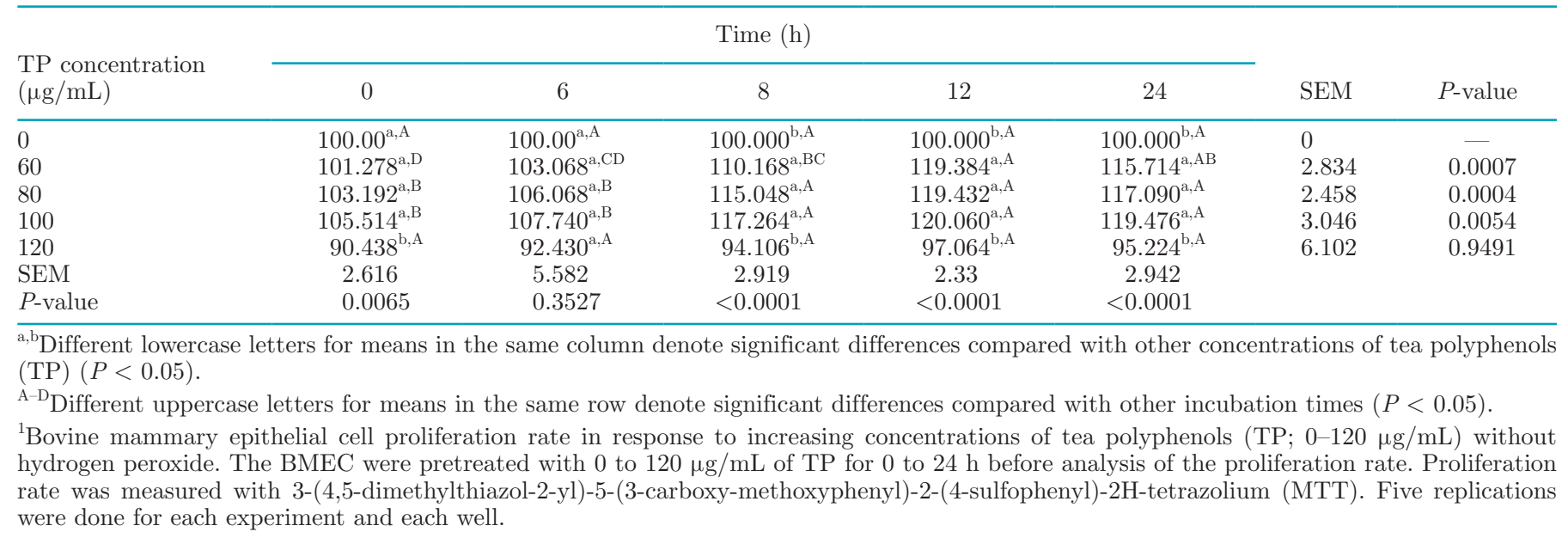



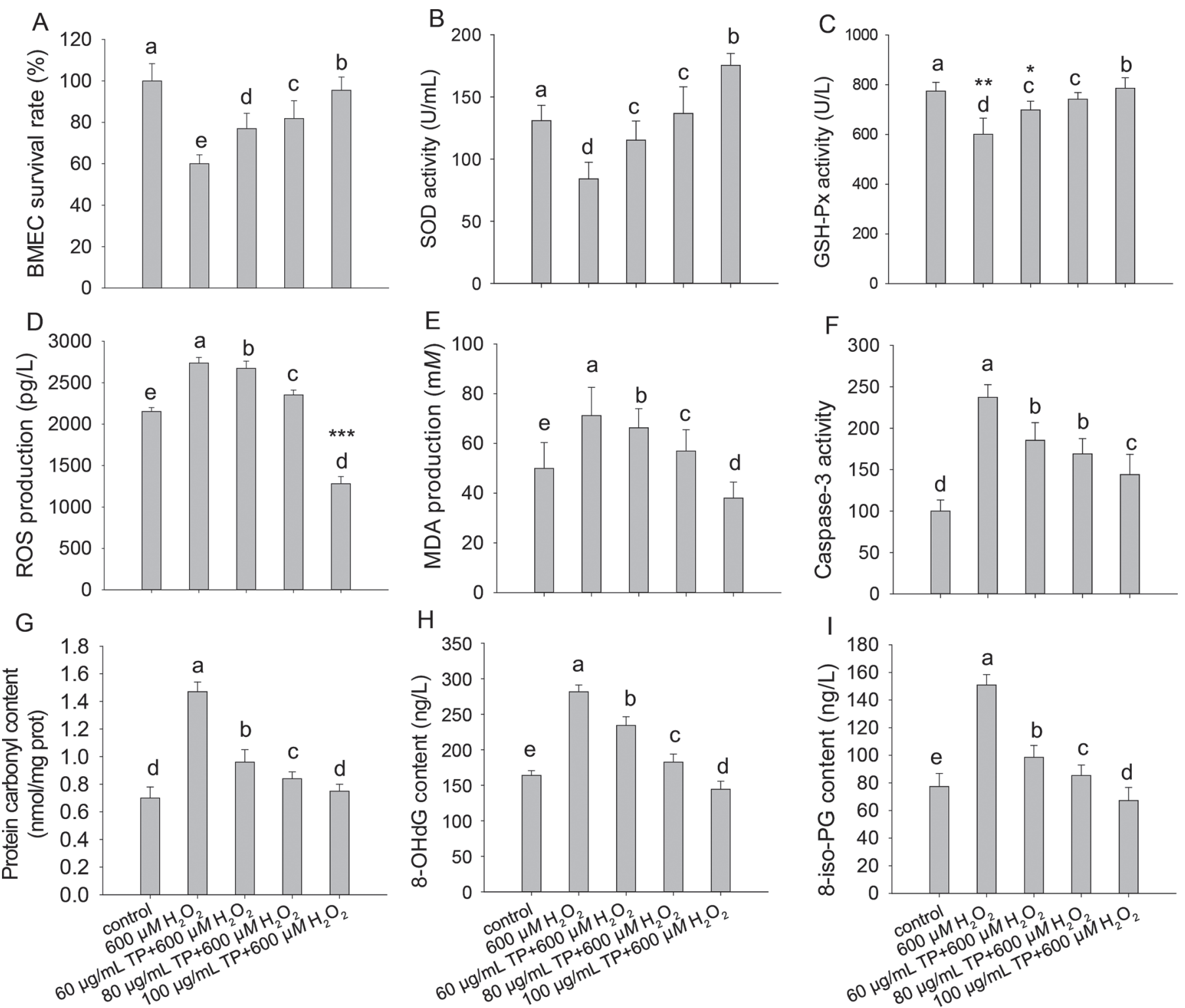

Figure 1. Screening for optimum conditions of tea polyphenol (TP) supplementation. Panels A-I: Cell survival rate, superoxide dismutase (SOD) and glutathione peroxidase (GSH-Px) activity, reactive oxygen species (ROS), and malondialdehyde (MDA) production, caspase-3 activity, protein carbonyl (PC), 8-hydroxydeoxyguanosine (8-OHdG), and 8-iso-prostaglandin (8-iso-PG) content in bovine mammary epithelial cells (BMEC) incubated without (control) or various levels of TP $(0-100 \mu \mathrm{g} / \mathrm{mL})$ with $\mathrm{H}_{2} \mathrm{O}_{2}$. The BMEC were pretreated with TP (0-100 $\mu \mathrm{g} /$ $\mathrm{mL}$ ) for $12 \mathrm{~h}$, followed by $\mathrm{H}_{2} \mathrm{O}_{2}(600 \mu M)$ challenge for $6 \mathrm{~h}$. Cell survival rate, SOD and GSH-Px activity, ROS and MDA production, caspase-3 activity, content of PC, 8-OHdG, and 8-iso-PG were determined. Cell survival rate was measured by 3-(4,5-dimethylthiazol-2-yl)-5-(3carboxymethoxyphenyl)-2-(4-sulfophenyl)-2H-tetrazolium (MTT) assay. Superoxide dismutase and GSH-Px activity, ROS and MDA production, caspase-3 activity, and content of PC, 8-OHdG, and 8-iso-PG were measured using commercial ELISA according to manufacturer's protocols. Means with different letters $(\mathrm{a}-\mathrm{c})$ differ $(P<0.05)$. Five replications were done for each experiment and each well. Values are means, with SE represented by vertical error bars.

alone $(P<0.01)$, pretreatment with $100 \mu \mathrm{g} / \mathrm{mL}$ of $\mathrm{TP}$ for $12 \mathrm{~h}$ followed by a $600 \mu M \mathrm{H}_{2} \mathrm{O}_{2}$ challenge for $6 \mathrm{~h}$ $\left(\mathrm{TP}+\mathrm{H}_{2} \mathrm{O}_{2}\right)$ increased survival rate. Transfection with NFE2L2-siRNA3, followed by pretreatment with TP $($ siRNA+TP), did not increase survival rate compared with cells siRNA transfection alone $(P=0.37)$. The survival rate of BMEC was lowest when cells were transfected with the NFE2L2-siRNA3 and treated with $\mathrm{H}_{2} \mathrm{O}_{2}\left(600 \mu M ;\right.$ siRNA $\left.+\mathrm{H}_{2} \mathrm{O}_{2}\right)$. Transfection with the NFE2L2-siRNA3 and pretreatment with TP followed by $\mathrm{H}_{2} \mathrm{O}_{2}$ ( $\mathrm{siRNA}+\mathrm{TP}+\mathrm{H}_{2} \mathrm{O}_{2}$ ) treatment improved survival rate compared with the $\mathrm{siRNA}^{+} \mathrm{H}_{2} \mathrm{O}_{2}$ treatment $(P<0.01)$. However, this improvement with TP was not as great as the survival rate of cells exposed to 
the $\mathrm{TP}+\mathrm{H}_{2} \mathrm{O}_{2}$ treatment. These results further suggest that the positive effect of TP on BMEC survival rate during challenge with $\mathrm{H}_{2} \mathrm{O}_{2}$ was impaired by silencing NFE2L2.

\section{Effect of $\mathrm{H}_{2} \mathrm{O}_{2}$ on ROS in BMEC After NFE2L2- siRNA3 Interference}

A triple interaction was observed between siRNA, TP, and $\mathrm{H}_{2} \mathrm{O}_{2}(P<0.01)$ for ROS production (Figure 6). The results demonstrated that $600 \mu M \mathrm{H}_{2} \mathrm{O}_{2}$ alone increased ROS production significantly compared with all other treatments $(P<0.05)$. Treatment with $\mathrm{TP}+\mathrm{H}_{2} \mathrm{O}_{2}$ significantly reduced ROS generation to the same level as siRNA and siRNA $+\mathrm{H}_{2} \mathrm{O}_{2}$ treatment $(P=0.01)$. The siRNA $+\mathrm{H}_{2} \mathrm{O}_{2}$ treatment increased ROS production compared with siRNA transfection alone $(P=0.02)$, whereas siRNA + TP did not alter ROS generation compared with siRNA alone $(P=$ $0.47)$. However, ROS generation was greatly increased in the siRNA $+\mathrm{TP}+\mathrm{H}_{2} \mathrm{O}_{2}$ treatment compared with siRNA $+\mathrm{H}_{2} \mathrm{O}_{2}$ and $\mathrm{TP}+\mathrm{H}_{2} \mathrm{O}_{2}$ treatments $(P<0.05)$, suggesting that the decrease in ROS production detected with TP was eliminated by silencing NFE2L2.

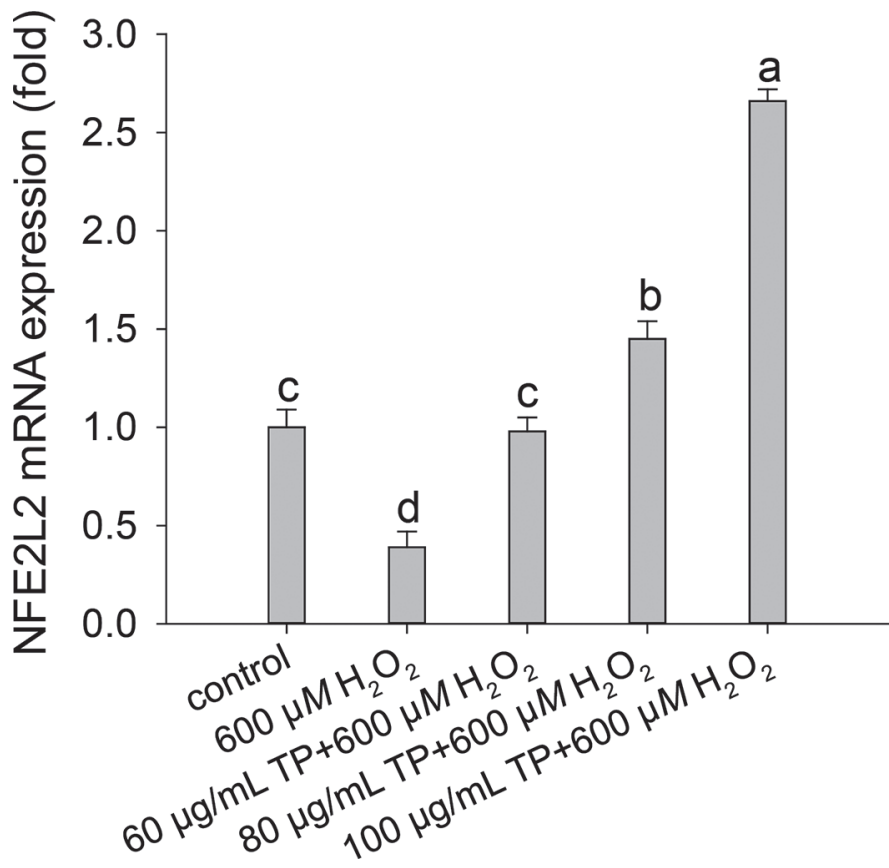

Figure 2. Cytoprotective effects of tea polyphenols (TP) on $\mathrm{H}_{2} \mathrm{O}_{2-}$ induced nuclear factor erythroid 2 like 2 (NFE2L2) mRNA expression in bovine mammary epithelial cells (BMEC). The BMEC were pretreated with TP $(0-100 \mu \mathrm{g} / \mathrm{mL})$ for $12 \mathrm{~h}$ and then treated with $\mathrm{H}_{2} \mathrm{O}_{2}$ $(600 \mu M)$ for $6 \mathrm{~h}$. The mRNA expression of NFE2L2 was analyzed by quantitative real-time PCR. Means with different letters (a-d) differ $(P<0.05)$. Five replications were done for each experiment and each well. Values are means, with SE represented by vertical error bars.
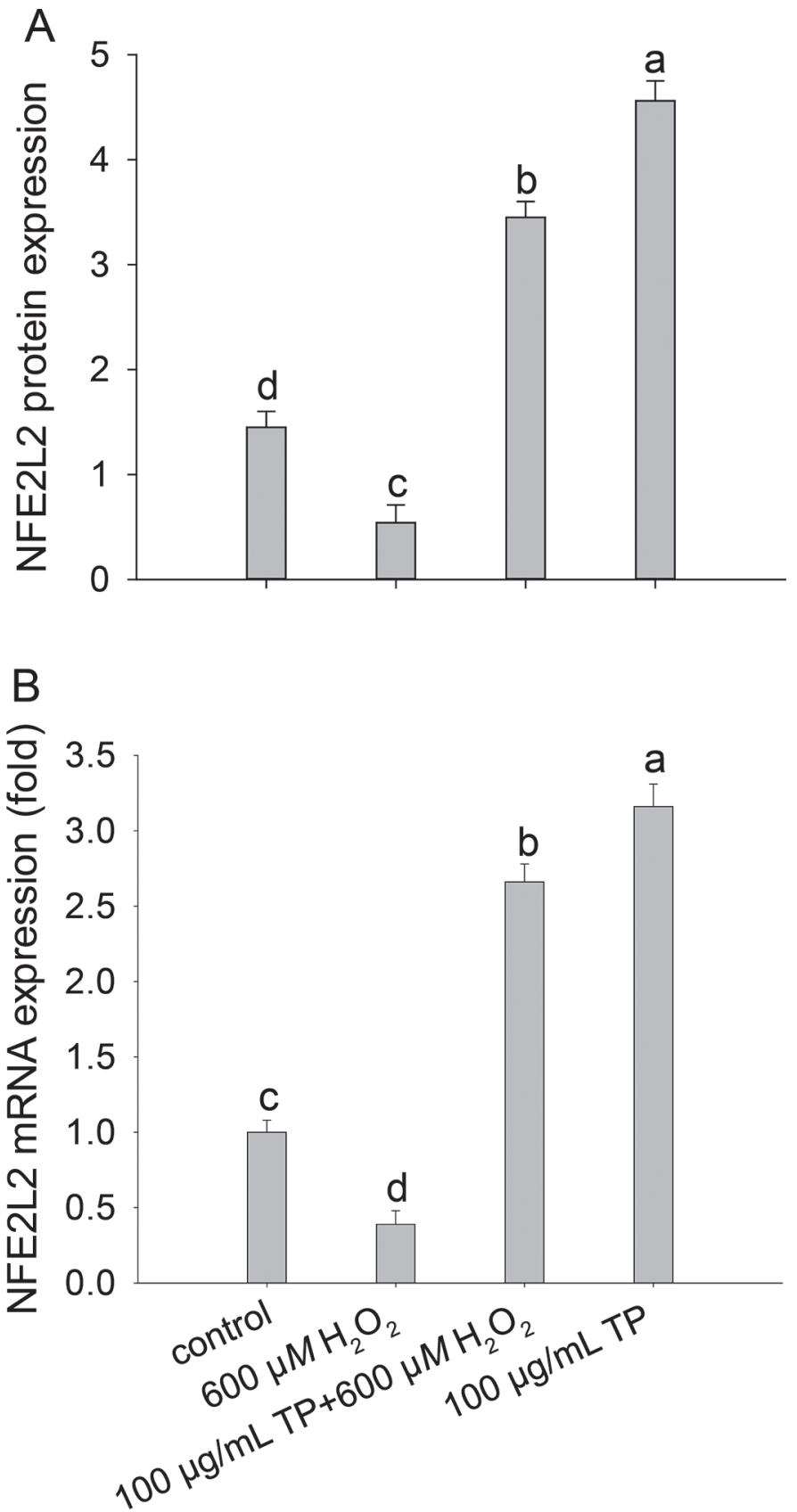

Figure 3. Effect of tea polyphenols (TP) on $\mathrm{H}_{2} \mathrm{O}_{2}$-induced nuclear factor erythroid 2 like 2 (NFE2L2) protein and mRNA expression. Panels A and B: Expression of NFE2L2 protein and mRNA in bovine mammary epithelial cells (BMEC) without (control) or with $\mathrm{H}_{2} \mathrm{O}_{2}$ and TP with or without $\mathrm{H}_{2} \mathrm{O}_{2}$. The BMEC were pretreated with or without $100 \mu \mathrm{g} / \mathrm{mL}$ of TP for $12 \mathrm{~h}$ and then treated with or without 600 $\mu M$ of $\mathrm{H}_{2} \mathrm{O}_{2}$ for $6 \mathrm{~h}$. The NFE2L2 protein and mRNA expression were analyzed by Western blot and quantitative real-time PCR. Means with different letters $(\mathrm{a}-\mathrm{d})$ differ $(P<0.05)$. Five replications were done for each experiment and each well. Values are means, with SE represented by vertical error bars. 


\section{Effect of $\mathrm{H}_{2} \mathrm{O}_{2}$ on NFE2L2 and Downstream Genes in BMEC After NFE2L2-siRNA3 Interference}

Triple interactions between siRNA, TP, and $\mathrm{H}_{2} \mathrm{O}_{2}$ were observed for the mRNA abundance of NFE2L2 $(P<0.01)$, HMOX1 $(P<0.01)$, and $G C L C(P<0.01$; Figure 7$)$.

Exogenous TP increased the mRNA abundance of NFE2L2 $(P<0.05)$ under normal conditions compared with the control cultures, and all other treatments. Importantly, transfection of NFE2L2-siRNA3 under normal conditions decreased the mRNA expression of NFE2L2 compared with control $(P<0.01)$, and expression was reduced the lowest when siRNA-transfected cells were treated with $\mathrm{H}_{2} \mathrm{O}_{2}$. Treatment with siRNA+TP increased the expression of NFE2L2 compared with siRNA alone $(P=0.01)$. The siRNA $+\mathrm{TP}+\mathrm{H}_{2} \mathrm{O}_{2}$ treatment increased NFE2L2 expression compared with the siRNA $+\mathrm{H}_{2} \mathrm{O}_{2}$ treatment $(P<0.01)$, but the increase in expression was still lower than observed with the $\mathrm{TP}+\mathrm{H}_{2} \mathrm{O}_{2}$ treatment $(P<0.01)$.

The mRNA expression of HMOX1 followed a similar pattern as NFE2L2; expression was increased with TP compared with control and all other treatments $(P<$

\section{A}
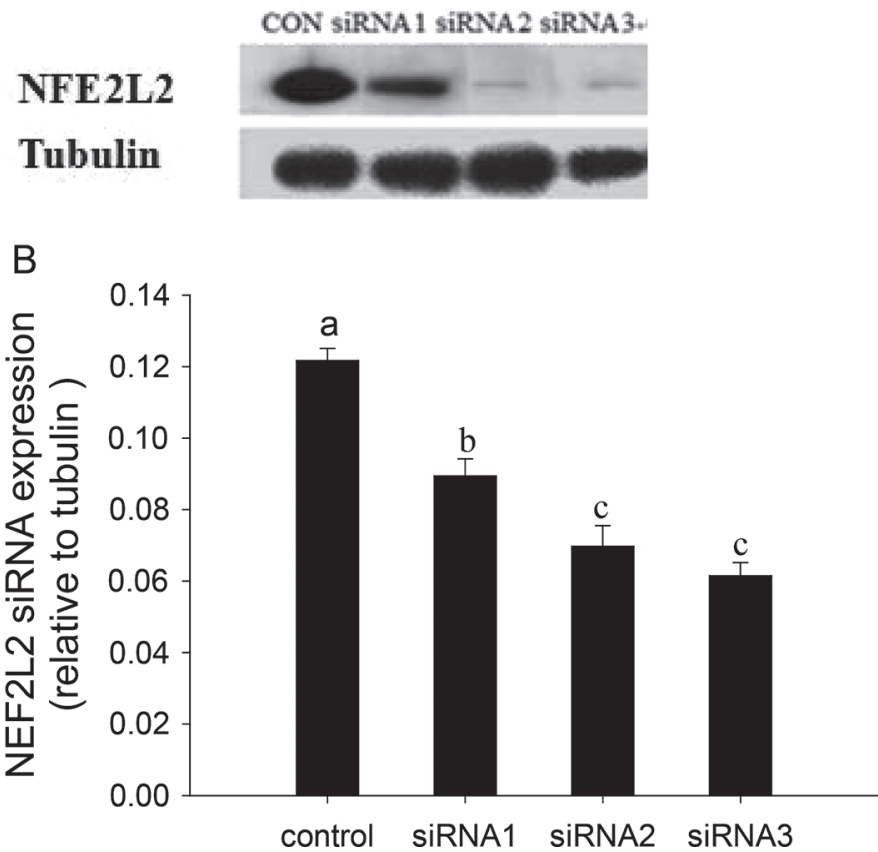

Figure 4. Screening for efficacy of nuclear factor erythroid 2 like 2 (NFE2L2)-short interfering RNA (siRNA) fragments. Panels A and B: protein and mRNA expression of NFE2L2 after siRNA treatment. Protein and mRNA expression of NFE2L2 after siRNA treatment was detected by Western blot and quantitative reverse-transcription PCR. Means with different letters $(\mathrm{a}-\mathrm{c})$ differ $(P<0.05)$. Five replications were done for each experiment and each well. Values are means, with SE represented by vertical error bars.

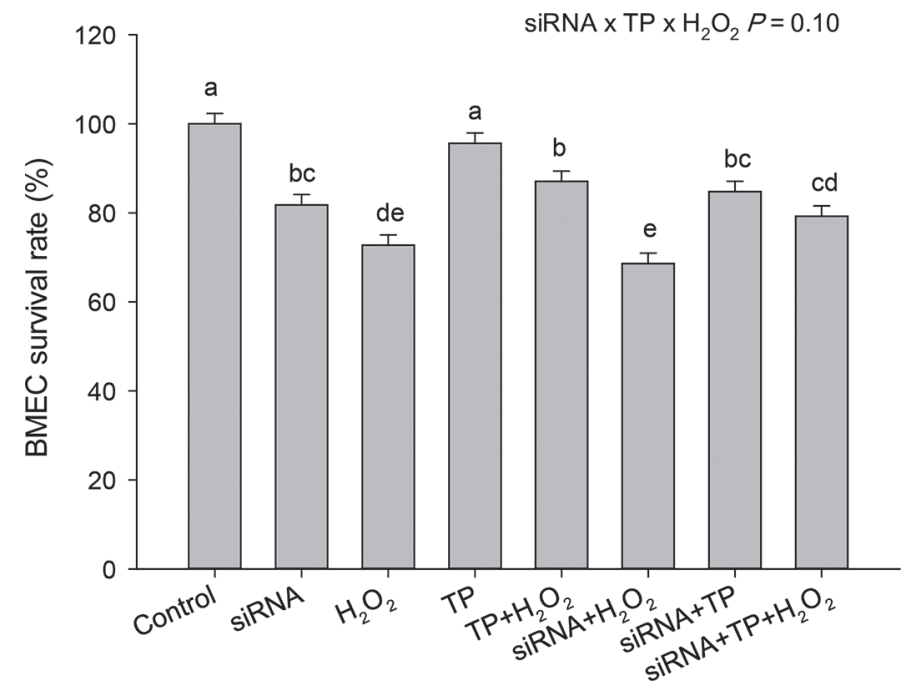

Figure 5. Effect of tea polyphenols (TP) on $\mathrm{H}_{2} \mathrm{O}_{2}$-induced bovine mammary epithelial cells (BMEC) survival rate in BMEC without TP, $\mathrm{H}_{2} \mathrm{O}_{2}$, or nuclear factor erythroid 2 like 2 (NFE2L2)-short interfering RNA (siRNA; control) with $\mathrm{H}_{2} \mathrm{O}_{2}$, TP without or with $\mathrm{H}_{2} \mathrm{O}_{2}$, NFE2L2siRNA3 without or with TP, NFE2L2-siRNA3 without or with $\mathrm{H}_{2} \mathrm{O}_{2}$, and NFE2L2-siRNA3 with TP and $\mathrm{H}_{2} \mathrm{O}_{2}$. The BMEC were transfected with NFE2L2-siRNA3, pretreated with or without $100 \mu \mathrm{g} / \mathrm{mL}$ of TP for $12 \mathrm{~h}$, and then treated with or without $600 \mu M \mathrm{H}_{2} \mathrm{O}_{2}$ for $6 \mathrm{~h}$. The BMEC survival rate was analyzed by 3-(4,5-dimethylthiazol-2-yl)5-(3-carboxymethoxyphenyl)-2-(4-sulfophenyl)-2H-tetrazolium (MTT) assay. Means with different letters $(\mathrm{a}-\mathrm{c})$ differ $(P<0.05)$. Five replications were done for each experiment and each well. Values are means, with SE represented by vertical error bars.

0.05; Figure 7). The addition of $\mathrm{TP}+\mathrm{H}_{2} \mathrm{O}_{2}$ increased HMOX1 expression compared with treatment with $\mathrm{H}_{2} \mathrm{O}_{2}$ alone $(P<0.01)$. However, when cells were exposed to the siRNA $+\mathrm{TP}+\mathrm{H}_{2} \mathrm{O}_{2}$ treatment, the mRNA expression of $H M O X 1$ was significantly lower than expression with the $\mathrm{TP}+\mathrm{H}_{2} \mathrm{O}_{2}$ treatment $(P<0.01)$, and was not different from the expression observed with the siRNA $+\mathrm{H}_{2} \mathrm{O}_{2}$ treatment $(P=0.38)$.

For $G C L C$, mRNA expression was greatest in cells treated with $\mathrm{TP}+\mathrm{H}_{2} \mathrm{O}_{2}$ compared with control and all other treatments $(P<0.05$; Figure 7$)$. When cells were exposed to the siRNA+TP $+\mathrm{H}_{2} \mathrm{O}_{2}$ treatment, GCLC expression was significantly lower than expression with $\mathrm{TP}+\mathrm{H}_{2} \mathrm{O}_{2}(P<0.01)$, and $G C L C$ expression tended to be altered compared with the siRNA $+\mathrm{H}_{2} \mathrm{O}_{2}$ treatment $(P=0.07)$.

A significant $\mathrm{TP} \times \mathrm{H}_{2} \mathrm{O}_{2}$ interaction was observed for the mRNA expression of NQO1 $(P<0.01$; Table 4); expression was greater with TP and $\mathrm{H}_{2} \mathrm{O}_{2}$ treatment compared with $\mathrm{H}_{2} \mathrm{O}_{2}$ alone $(P<0.01)$. An siRNA $\times$ TP interaction was also observed for $N Q O 1(P=0.01)$ where siRNA and TP tended to have a greater expression than siRNA alone $(P=0.94)$ but was lower than $\mathrm{TP}$ alone $(P<0.01)$. Additionally, there was a tendency for an siRNA $\times \mathrm{H}_{2} \mathrm{O}_{2}$ interaction for the mRNA 


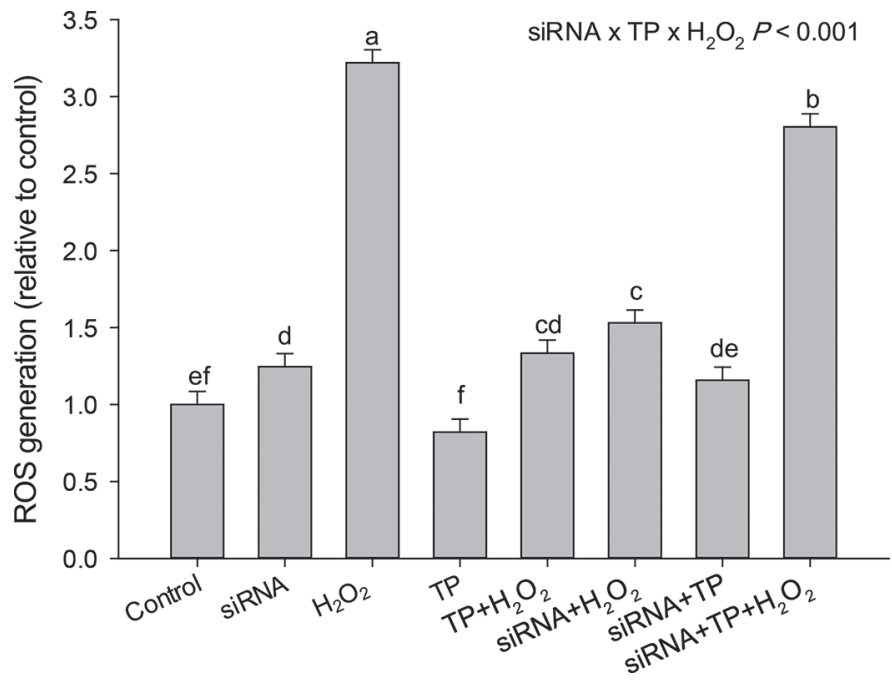

Figure 6. Effect of tea polyphenols (TP) on $\mathrm{H}_{2} \mathrm{O}_{2}$-induced reactive oxygen species (ROS) generation in bovine mammary epithelial cells (BMEC) without TP, $\mathrm{H}_{2} \mathrm{O}_{2}$, or nuclear factor erythroid 2 like 2 (NFE2L2)-short interfering RNA (siRNA; control) with $\mathrm{H}_{2} \mathrm{O}_{2}$, TP without or with $\mathrm{H}_{2} \mathrm{O}_{2}$, NFE2L2-siRNA3 without or with TP, NFE2L2siRNA3 without or with $\mathrm{H}_{2} \mathrm{O}_{2}$, and NFE2L2-siRNA3 with TP and $\mathrm{H}_{2} \mathrm{O}_{2}$. The BMEC were transfected with NFE2L2-siRNA3, pretreated with or without $100 \mu \mathrm{g} / \mathrm{mL}$ of TP for $12 \mathrm{~h}$, and then treated with or without $600 \mu \mathrm{M}$ of $\mathrm{H}_{2} \mathrm{O}_{2}$ for $6 \mathrm{~h}$. The generation of ROS was analyzed with a commercial kit following the manufacturer's recommendations. Means with different letters $(\mathrm{a}-\mathrm{f})$ differ $(P<0.05)$. Five replications were done for each experiment and each well. Values are means, with $\mathrm{SE}$ represented by vertical error bars.

expression of $N Q O 1(P=0.07)$ where the addition of siRNA and $\mathrm{H}_{2} \mathrm{O}_{2}$ significantly reduced the expression of NQO1 compared with addition of $\mathrm{H}_{2} \mathrm{O}_{2}$ alone $(P<$ $0.01)$.

A significant siRNA $\times$ TP interaction was also observed for the mRNA expression of $G C L M(P<0.01$; Table 4). The expression of GCLM was greater with TP alone versus siRNA or siRNA with TP $(P<0.01)$, and expression was not different between siRNA and siRNA with TP $(P=0.47)$. A significant TP $\times \mathrm{H}_{2} \mathrm{O}_{2}$ interaction was also observed for the mRNA expression of GCLM $\left(P<0.01\right.$; Table 4) where $\mathrm{TP}+\mathrm{H}_{2} \mathrm{O}_{2}$ increased the expression of GCLM compared with $\mathrm{H}_{2} \mathrm{O}_{2}$ alone $(P=0.01)$. These results further suggested that the positive effect of TP on the mRNA abundance of NFE2L2 and 4 main phase-II detoxifying enzyme was eliminated by silencing NFE2L2.

\section{DISCUSSION}

In the present study, we demonstrated that TP could play an important role in antioxidant protection of BMEC. Exogenous TP activates NFE2L2 and the HMOX1 and NQO1 pathway in part by upregulating the steady-state level of NFE2L2 protein and mRNA.
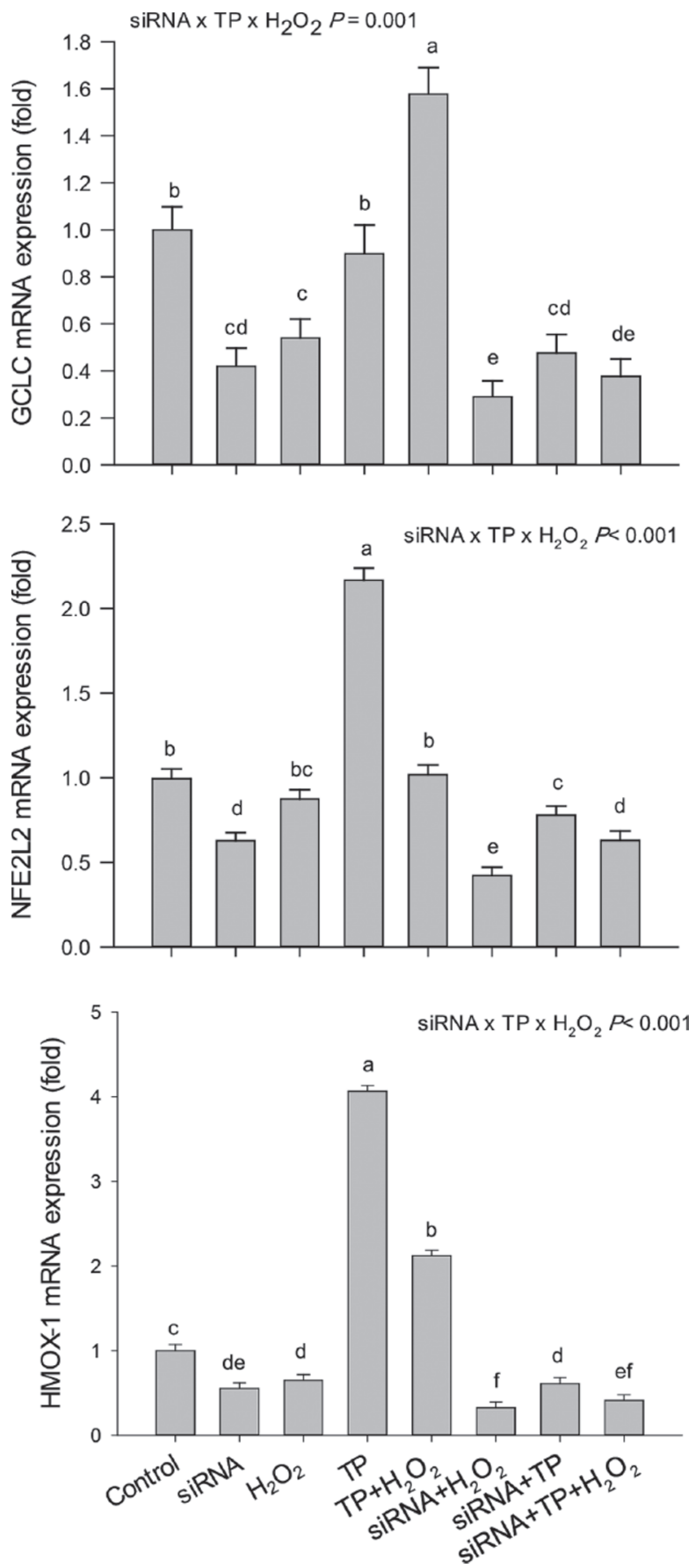

Figure 7. Effect of tea polyphenols (TP) on $\mathrm{H}_{2} \mathrm{O}_{2}$-induced mRNA expression of NFE2L2, HMOX1, and GCLC in bovine mammary epithelial cells (BMEC). Panels A-E: The mRNA expression of NFE2L2, $H M O X 1$, and $G C L C$ in BMEC without TP, $\mathrm{H}_{2} \mathrm{O}_{2}$, or nuclear factor erythroid 2 like 2 (NFE2L2)-siRNA (control) with $\mathrm{H}_{2} \mathrm{O}_{2}$, TP without or with $\mathrm{H}_{2} \mathrm{O}_{2}$, NFE2L2-siRNA3 without or with TP, NFE2L2-siRNA3 without or with $\mathrm{H}_{2} \mathrm{O}_{2}$, and NFE2L2-siRNA3 with TP and $\mathrm{H}_{2} \mathrm{O}_{2}$. The BMEC were transfected with NFE2L2-siRNA3, pretreated with or without $100 \mu \mathrm{g} / \mathrm{mL}$ of TP for $12 \mathrm{~h}$, and then treated with or without $600 \mu \mathrm{M}$ of $\mathrm{H}_{2} \mathrm{O}_{2}$ for $6 \mathrm{~h}$. The mRNA expression of NFE2L2, HMOX1, $N Q O 1, G C L C$, and $G C L M$ was analyzed by quantitative reverse-transcription PCR. Means with different letters $(\mathrm{a}-\mathrm{f})$ differ $(P<0.05)$. Five replications were done for each experiment and each well. Values are means, with SE represented by vertical error bars. 


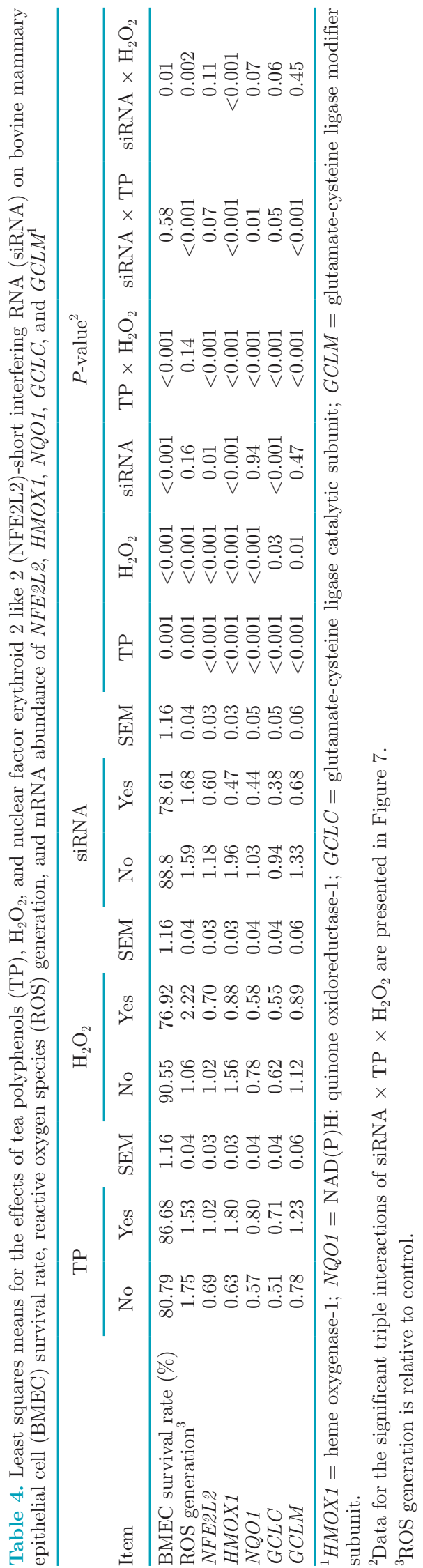

These results are consistent with in vitro observations that quercetin, a polyphenolic compound, can enhance NFE2L2 transcription activity, upregulate the mRNA and protein expression of NFE2L2, and increase the expression of NQO1 (Tanigawa et al., 2007). Together, these effects of TP might coordinate the antioxidant response when BMEC are challenged with ROS including $\mathrm{H}_{2} \mathrm{O}_{2}$.

First discovered in China, tea is grown in over 30 countries and aside from water is the most widely consumed beverage in the world (Graham, 1992). In vitro and in vivo evidence with nonruminant cells suggests that TP are effective antioxidants against ROS-induced disorders (Wiseman et al., 1997). A key function of $\mathrm{TP}$ is to both scavenge ROS directly and stimulate endogenous cellular defense systems (Shi et al., 2000) with antioxidant roles (Frei and Higdon, 2003; McMahon et al., 2004). Thus, by challenging BMEC with a supraphysiologic dose of $\mathrm{H}_{2} \mathrm{O}_{2}$ and providing exogenous TP, the present study demonstrated a positive effect on activity of SOD and GSH-Px, accompanied by decreases in concentrations of ROS, MDA, and the activity of caspase-3. The decrease in concentrations of $\mathrm{PC}, 8-\mathrm{OHdG}$, and 8-iso-PG under OS conditions also underscored that the positive effect of TP extends to reducing the damage of proteins, DNA, and lipids.

The NFE2L2 can regulate antioxidant responses by activating the downstream phase-II detoxifying genes such as HOMX-1, NQO1, GCLC, and GCLM. Previous studies revealed that activation of NFE2L2 expression enhanced cell survival rate under OS (Duan et al., 2017), and NFE2L2 activation was central to the upregulation of antioxidant enzyme expression (Hyung et al., 2016). The present results are consistent with those findings and underscore the potency of TP for suppressing OS-induced injury (Wu et al., 2015; Lan et al., 2016; Shi et al., 2018).

A direct role for TP and components of the NFE2L2 in the antioxidant response was confirmed when silencing of NFE2L2 led to a strong inhibition of the antioxidant function of TP (i.e., the survival rate of BMEC and mRNA expression of NFE2L2 and downstream genes were decreased while ROS generation was increased). The lack of change in BMEC survival rate, GCLC and HMOX1 mRNA expression, and ROS production when NFE2L2 was silenced with or without TP along with the failure of TP to decrease ROS production when NFE2L2 was silenced under OS status further indicated that the NFE2L2 pathway is very important for TP to protect BMEC against OS induced by $\mathrm{H}_{2} \mathrm{O}_{2}$. In other words, silencing of NFE2L2 failed to activate the antioxidant functions of TP. Taken together, these data illustrated clearly that NFE2L2 was a key component of the antioxidant response induced by TP. Further 
research will have to be performed to evaluate these mechanisms in vivo.

From a mechanistic standpoint, and similar to nonruminant studies, the data indicate that $\mathrm{TP}$ pretreatment elicits an antioxidant response via increasing the activation of NFE2L2/HMOX1 pathway (Lee et al., 1995; Skrzydlewska et al., 2002). Therefore, these data provide further support for a biological role of the NFE2L2 pathway in mammary tissue, and emphasize a potential benefit for increasing the supply of TP via dietary supplementation.

\section{CONCLUSIONS}

Tea polyphenols in vitro can alleviate $\mathrm{H}_{2} \mathrm{O}_{2}$-induced oxidative damage of mammary epithelial cells by controlling the production of ROS and MDA, PC, 8-OHdG, and 8-iso-PG, and the activity of caspase-3. They do this in part by increasing the activity of antioxidant enzymes such as SOD and GSH-Px, and the protein and mRNA abundance of NFE2L2. The fact that silencing of NFE2L2 failed to activate antioxidant mechanisms, even when TP was added, underscored its importance in the overall control of oxidative stress. Hence, the control of NFE2L2 and downstream target genes and proteins constitute important mechanisms for TP action against oxidative stress.

\section{ACKNOWLEDGMENTS}

This research was supported by grants from National Natural Science Foundation of China (no. 31601975 and no. 31460616) and from the China Agriculture Research System (no. CARS-36). Y. Ma received a China Scholarship Council (Beijing) fellowship to train at the University of Illinois.

\section{REFERENCES}

Abuelo, A., J. Hernandez, J. L. Benedito, and C. Castillo. 2016. Association of oxidative status and insulin sensitivity in periparturient dairy cattle: An observational study. J. Anim. Physiol. Anim. Nutr. (Berl.) 100:279-286.

Bertoni, G., E. Trevisi, X. Han, and M. Bionaz. 2008. Effects of inflammatory conditions on liver activity in puerperium period and consequences for performance in dairy cows. J. Dairy Sci. 91:33003310 .

Denzer, I., G. Münch, and K. Friedland. 2016. Modulation of mitochondrial dysfunction in neurodegenerative diseases via activation of nuclear factor erythroid-2-related factor 2 by food-derived compounds. Pharmacol. Res. 103:80-94.

Duan, J., Y. Guan, F. Mu, C. Guo, E. Zhang, Y. Yin, G. Wei, Y. Zhu, J. Cui, J. Cao, Y. Weng, Y. Wang, M. Xi, and A. Wen. 2017. Protective effect of butin against ischemia/reperfusion-induced myocardial injury in diabetic mice: Involvement of the AMPK/ GSK-3beta/Nrf2 signaling pathway. Sci. Rep. 7:41491.

Favreau, L. V., and C. B. Pickett. 1995. The rat quinone reductase antioxidant response element. Identification of the nucleotide sequence required for basal and inducible activity and detection of antioxidant response element-binding proteins in hepatoma and non-hepatoma cell lines. J. Biol. Chem. 270:24468-24474.

Frei, B., and J. Higdon. 2003. Antioxidant activity of tea polyphenols in vivo: Evidence from animal studies. J. Nutr. 133:3275S-3284S.

Graham, H. 1992. Green tea composition, consumption, and polyphenol chemistry. Prev. Med. 21:334-350.

Han, L., F. Batistel, Y. Ma, A. S. M. Alharthi, C. Parys, and J. J. Loor. 2018a. Methionine supply alters mammary gland antioxidant gene networks via phosphorylation of nuclear factor erythroid 2-like 2 (NFE2L2) protein in dairy cows during the periparturient period. J. Dairy Sci. 101:8505-8512. https://doi.org/10.3168/jds .2017-14206

Han, L. Q., Z. Zhou, Y. Ma, F. Batistel, J. S. Osorio, and J. J. Loor. 2018b. Phosphorylation of nuclear factor erythroid 2-like 2 (NFE2L2) in mammary tissue of Holstein cows during the periparturient period is associated with mRNA abundance of antioxidant gene networks. J. Dairy Sci. 101:6511-6522.

Hayes, J., and M. McMahon. 2001. Molecular basis for the contribution of the antioxidant responsive element to cancer chemoprevention. Cancer Lett. 174:103-113.

Hyung, J. H., C. B. Ahn, B. Il Kim, K. Kim, and J. Y. Je. 2016. Involvement of Nrf2-mediated heme oxygenase-1 expression in antiinflammatory action of chitosan oligosaccharides through MAPK activation in murine macrophages. Eur. J. Pharmacol. 793:43-48.

Inamdar, N., Y. Ahn, and J. Alam. 1996. The heme-responsive element of the mouse heme oxygenase- 1 gene is an extended AP-1 binding site that resembles the recognition sequences for MAF and NF-E2 transcription factors. Biochem. Biophys. Res. Commun. 221:570-576.

Ishii, T., K. Itoh, S. Takahashi, H. Sato, T. Yanagawa, Y. Katoh, S. Bannai, and M. Yamamoto. 2000. Transcription factor Nrf2 coordinately regulates a group of oxidative stress-inducible genes in macrophages. J. Biol. Chem. 275:16023-16029.

Itoh, K., T. Chiba, S. Takahashi, T. Ishii, K. Igarashi, Y. Katoh, T. Oyake, N. Hayashi, K. Satoh, I. Hatayama, M. Yamamoto, and Y. Nabeshima. 1997. An Nrf2/small Maf heterodimer mediates the induction of phase II detoxifying enzyme genes through antioxidant response elements. Biochem. Biophys. Res. Commun. 236:313-322.

Itoh, K., M. Mochizuki, Y. Ishii, T. Ishii, T. Shibata, Y. Kawamoto, V. Kelly, K. Sekizawa, K. Uchida, and M. Yamamoto. 2004. Transcription factor Nrf2 regulates inflammation by mediating the effect of 15-deoxy-Delta(12,14)-prostaglandin j(2). Mol. Cell. Biol. $24: 36-45$

Jaiswal, A. 2004. Nrf2 signaling in coordinated activation of antioxidant gene expression. Free Radic. Biol. Med. 36:1199-1207.

Jin, X., K. Wang, H. Liu, F. Hu, F. Zhao, and J. Liu. 2016. Protection of bovine mammary epithelial cells from hydrogen peroxideinduced oxidative cell damage by resveratrol. Oxid. Med. Cell. Longev. 2016:2572175

Kaneko, T., S. Tahara, and M. Matsuo. 1996. Non-linear accumulation of 8-hydroxy-2'-deoxyguanosine, a marker of oxidized DNA damage, during aging. Mutat. Res. 316:277-285.

Kansanen, E., S. M. Kuosmanen, H. Leinonen, and A. L. Levonen. 2013. The Keap1-Nrf2 pathway: Mechanisms of activation and dysregulation in cancer. Redox Biol. 1:45-49.

Khan, M. J., C. B. Jacometo, D. E. Graugnard, M. N. Corrêa, E. Schmitt, F. C. Cardoso, and J. J. Loor. 2014. Overfeeding dairy cattle during late-pregnancy alters hepatic PPAR $\alpha$-regulated pathways including hepatokines: Impact on metabolism and peripheral insulin sensitivity. Gene Regul. Syst. Bio. 8:97-111. https: //doi.org/10.4137/GRSB.S14116.

Kobayashi, M., and M. Yamamoto. 2006. Nrf2-Keap1 regulation of cellular defense mechanisms against electrophiles and reactive oxygen species. Adv. Enzyme Regul. 46:113-140.

Kweon, M., V. Adhami, J. Lee, and H. Mukhtar. 2006. Constitutive overexpression of Nrf2-dependent heme oxygenase-1 in A549 cells contributes to resistance to apoptosis induced by epigallocatechin 3-gallate. J. Biol. Chem. 281:33761-33772.

Lan, A., W. Li, Y. Liu, Z. Xiong, X. Zhang, S. Zhou, O. Palko, H Chen, M. Kapita, J. R. Prigge, E. E. Schmidt, X. Chen, Z. Sun, 
and X. L. Chen. 2016. Chemoprevention of oxidative stress-associated oral carcinogenesis by sulforaphane depends on NRF2 and the isothiocyanate moiety. Oncotarget 7:53502-53514.

Lee, S., Y. Liang, and J. Lin. 1995. Inhibition of 1,2,4-benzenetriolgenerated active oxygen species and induction of phase II enzymes by green tea polyphenols. Chem. Biol. Interact. 98:283-301.

Ljubisavljevic, S., I. Stojanovic, D. Pavlovic, M. Milojkovic, D. Sokolovic, I. Stevanovic, and A. Petrovic. 2013. Suppression of the lipid peroxidation process in the CNS reduces neurological expression of experimentally induced autoimmune encephalomyelitis. Folia Neuropathol. 51:51-57.

Loor, J. J. 2010. Genomics of metabolic adaptations in the peripartal cow. Animal 4:1110-1139.

Loor, J. J., M. Bionaz, and J. K. Drackley. 2013. Systems physiology in dairy cattle: Nutritional genomics and beyond. Annu. Rev. Anim. Biosci. 1:365-392. https://doi.org/10.1146/annurev-animal -031412-103728.

Ma, Y. F., Z. H. Wu, M. Gao, and J. J. Loor. 2018a. Nuclear factorlike factor 2-antioxidant activation through the action of ataxia telangiectasia-mutated serine/threonine kinase is essential to counteract oxidative stress in bovine mammary epithelial cells. J. Dairy Sci. 101:5317-5328.

Ma, Y. F., Z. H. Wu, M. Gao, and J. J. Loor. 2018b. Nuclear factor erythroid 2-related factor 2 antioxidant response element pathways protect bovine mammary epithelial cells against $\mathrm{H}_{2} \mathrm{O}_{2}$-induced oxidative damage in vitro. J. Dairy Sci. 101:5329-5344.

McMahon, M., N. Thomas, K. Itoh, M. Yamamoto, and J. Hayes. 2004. Redox-regulated turnover of Nrf2 is determined by at least two separate protein domains, the redox-sensitive Neh2 degron and the redox-insensitive Neh6 degron. J. Biol. Chem. 279:3155631567.

Milaneschi, Y., M. Cesari, E. M. Simonsick, N. Vogelzangs, A. M. Kanaya, K. Yaffe, P. Patrignani, A. Metti, S. B. Kritchevsky, M. Pahor, L. Ferrucci, B. W. Penninx, and Health ABC study. 2013. Lipid peroxidation and depressed mood in community-dwelling older men and women. PLoS One 8:e65406.

Nguyen, T., P. Sherratt, and C. Pickett. 2003. Regulatory mechanisms controlling gene expression mediated by the antioxidant response element. Annu. Rev. Pharmacol. Toxicol. 43:233-260.

Osorio, J. S., P. Ji, J. K. Drackley, D. Luchini, and J. J. Loor. 2014 Smartamine $\mathrm{M}$ and MetaSmart supplementation during the peripartal period alter hepatic expression of gene networks in 1-carbon metabolism, inflammation, oxidative stress, and the growth hormone-insulin-like growth factor 1 axis pathways. J. Dairy Sci. 97:7451-7464

Ryter, S., and A. Choi. 2005. Heme oxygenase-1: Redox regulation of a stress protein in lung and cell culture models. Antioxid. Redox Signal. 7:80-91

Shi, J., M. Zhang, L. Zhang, and H. Deng. 2018. Epigallocatechin3 -gallate attenuates microcystin-LR-induced apoptosis in human umbilical vein endothelial cells through activation of the NRF2/ HO-1 pathway. Environ. Pollut. 239:466-472.
Shi, X., J. Ye, S. Leonard, M. Ding, V. Vallyathan, V. Castranova Y. Rojanasakul, and Z. Dong. 2000. Antioxidant properties of (-)-epicatechin-3-gallate and its inhibition of $\mathrm{Cr}(\mathrm{VI})$-induced DNA damage and $\mathrm{Cr}(\mathrm{IV})$ - or TPA-stimulated NF-kappaB activation. Mol. Cell. Biochem. 206:125-132.

Skrzydlewska, E., J. Ostrowska, R. Farbiszewski, and K. Michalak. 2002. Protective effect of green tea against lipid peroxidation in the rat liver, blood serum and the brain. Phytomedicine 9:232-238.

Soberanes, S., V. Panduri, G. Mutlu, A. Ghio, G. Bundinger, and D. Kamp. 2006. p53 mediates particulate matter-induced alveolar epithelial cell mitochondria-regulated apoptosis. Am. J. Respir. Crit. Care Med. 174:1229-1238.

Sordillo, L. M., and W. Raphael. 2013. Significance of metabolic stress, lipid mobilization, and inflammation on transition cow disorders. Vet. Clin. North Am. Food Anim. Pract. 29:267-278.

Tanigawa, S., M. Fujii, and D. Hou. 2007. Action of Nrf2 and Keap1 in ARE-mediated NQO1 expression by quercetin. Free Radic. Biol. Med. 42:1690-1703.

Vitaglione, P., F. Morisco, N. Caporaso, and V. Fogliano. 2004. Dietary antioxidant compounds and liver health. Crit. Rev. Food Sci. Nutr. 44:575-586.

Wang, M. Z., B. L. Xu, H. R. Wang, D. P. Bu, J. Q. Wang, and J. J. Loor. 2014. Effect of arginine concentration on the in vitro expression of casein and mTOR pathway related genes in mammary epithelial cells from dairy cattle. PLoS One 9:1-8.

Weber, D., M. J. Davies, and T. Grune. 2015. Determination of protein carbonyls in plasma, cell extracts, tissue homogenates, isolated proteins: Focus on sample preparation and derivatization conditions. Redox Biol. 5:367-380.

Wiseman, S., D. Balentine, and B. Frei. 1997. Antioxidants in tea. Crit. Rev. Food Sci. Nutr. 37:705-718.

Wu, H., L. Kong, Y. Cheng, Z. Zhang, Y. Wang, M. Luo, Y. Tan, X. Chen, L. Miao, and L. Cai. 2015. Metallothionein plays a prominent role in the prevention of diabetic nephropathy by sulforaphane via up-regulation of Nrf2. Free Radic. Biol. Med. 89:431-442.

Zhang, Q., J. Pi, C. G. Woods, and M. E. Andersen. 2010. A systems biology perspective on Nrf2-mediated antioxidant response. Toxicol. Appl. Pharmacol. 244:84-97.

Zhou, Z., O. Bulgari, M. Vailati-Riboni, E. Trevisi, M. A. Ballou, F. C. Cardoso, D. N. Luchini, and J. J. Loor. 2016a. Rumen-protected methionine compared with rumen-protected choline improves immunometabolic status in dairy cows during the peripartal period. J. Dairy Sci. 99:8956-8969. https://doi.org/10.3168/jds.2016 -10986 .

Zhou, Z., M. Vailati-Riboni, E. Trevisi, J. K. Drackley, D. N. Luchini, and J. J. Loor. 2016b. Better postpartal performance in dairy cows supplemented with rumen-protected methionine compared with choline during the peripartal period. J. Dairy Sci. 99:8716-8732. https://doi.org/10.3168/jds.2015-10525. 